\title{
SPATIAL PARAMETERS OF STATOGRAMS IN DIAGNOSING PATHOLOGIES OF THE HUMAN LOCOMOTOR SYSTEM
}

\author{
Sergii Pavlov ${ }^{1}$, Yurii Bezsmertnyi ${ }^{2}$, Stanislav Iaremyn $^{2}$, Halyna Bezsmertna ${ }^{2}$ \\ ${ }^{1}$ Vinnytsia National Technical University, Vinnytsia, Ukraine, ${ }^{2}$ Scientific Research Institute of Invalid Rehabilitation on the base of Vinnitsa Pirogov National Medical \\ University, Vinnytsia, Ukraine
}

\begin{abstract}
The analysis of the spatial parameters of statograms in terms of the projection area of the common center of mass (CCM) in single and double support was performed, along with the magnitude of the total maximum area of the statogram and its relation to the area of the projection spot for each type of standing, and the area of the statogram according to the mathematical expectation. The high sensitivity of the spatial parameters of statograms is indicated by the values of the CCM spot plane in the case of single support, the ratio of the planes, and the angular asymmetry. The analysis of the parameters of statograms showed that for all types of standing volunteers of the control group, the area of the projection spot of the CCM was the smallest in both two-pronged standing, and in single support standing. In patients with osteochondrosis and with coxarthrosis (CA), the area of the spots was much larger, with a statistically significant difference observed in single support ( $p<0.05$ ). The ratio of the planes was statistically different between groups $(p=0.043)$ : in the control group it was the maximum (0.38), which reflects the highest ability to maintain equilibrium, and the minimum (0.25) - in the group of patients with CA. An analysis of variance revealed a significant difference $(p=0.025)$ of asymmetry in body angle $K_{\alpha}$ between the study groups.
\end{abstract} The angle of the body rotation $K_{\beta}$ in the case of single support is not statistically different in the study groups (p = 0.294), but this indicator can be considered as prognostic in terms of the diagnosis of pathology of the musculoskeletal system.

Keywords: spatial parameters, statogram, the common center of mass, locomotor system

\section{PARAMETRY PRZESTRZENNE STATOGRAMÓW W DIAGNOSTYCE PATOLOGII UKLADU MIĘŚNIOWO-SZKIELETOWEGO}

Streszczenie. Analiza parametrów przestrzennych statogramów za pomoca wskaźników obszaru rzutu całkowitego środka masy (ZCM) dla podparcia pojedynczego i podwójnego, wielkości całkowitego maksymalnego pola statogramu i stosunku powierzchni miejsca projekcji dla każdego rodzaju stania, obszaru statogramu zgodnie z oczekiwaniami matematycznymi. Analiza parametrów stabilogramów wykazała, że dla wszystkich typów ochotników stojacych $w$ grupie kontrolnej obszar miejsca projekcji ZCM byt najmniejszy zarówno w przypadku dwóch stanowisk, jak i jednego stanowiska. U pacjentów z osteochondroza odcinka ledźwiowego kregostupa i statku kosmicznego powierzchnia plam była znacznie większa, z istotna statystycznie różnica $(p<0,05)$ w pozycji stojącej. Stosunek płaszczyzn byt statystycznie różny między grupami $(p=0,043)$ : $w$ płaszczyźnie kontrolnej byt to maksimum (0,38), co odzwierciedla najwyższa zdolność do utrzymania równowagi, a minimum $(0,25)$ - w grupie pacjentów z KA. Analiza wariancji wykazała znaczaca różnice $(p=0,025)$ asymetrii $w$ kacie obrotu ciała $K_{\alpha}$ między badanymi grupami. Kąt obrotu ciała $K_{\beta} w$ przypadku pojedynczego podparcia nie jest statystycznie różny $w$ grupach badanych $(p=0,294)$, ale wskaźnik ten można uznać za prognostyczny pod względem diagnozy patologii układu mięśniowo-szkieletowego.

Słowa kluczowe: parametry przestrzenne, statogram, wspólny środek masy, układ mięśniowo-szkieletowy

\section{Introduction}

One of the methods of clinical biomechanics for the study of the locomotor system (LS) is to study the features of standing, namely, maintaining a vertical posture $[13,16]$. Clinical analysis of standing has long been recognized as one of the most effective methods of diagnosis of various types of congenital and acquired pathology of the support and movement system [4 5, 10]. Despite the almost century-old history of the use of the method of statography, its weak point remains the limited possibility of differential diagnosis of various elements of the LS. Therefore, the efforts of biomechanics today are aimed at finding diagnostic criteria for statograms that would be able to identify abnormalities in individual elements of the LS. Another problem is that different researchers evaluate statistics using different criteria and coefficients, which makes it difficult to compare and generalize the results obtained $[3,8,9]$.

\section{Analysis of recent research and publications}

In our practice, the criteria of statograms are the coefficients of vacillation and stability, maximum deviation in the frontal and sagittal planes in the conditions of two-legged standing and standing with the predominant load on one limb [15]. Some researchers have suggested other indicators of estimating statograms: the length of the trajectory of moving the center of gravity, the area of the statogram, the ratio of the length of the statogram to its area, as well as the statistical parameters of time series $[6,14]$. In statographic foreign studies, it is preferable to measure such parameters as the length of the trajectory, the rocking area, the speed and frequency characteristics of the statograms, so the set of parameters of the statograms is much wider $[11,17]$. One of the areas of work was replenishment of the arsenal of parameters of the estimation of statograms, as well as mathematical justification of the possibility of their use for differential diagnosis of pathology of LS, in particular the lumbar spine. Analyzing the statograms of patients with different pathological conditions of LS, we noted that the spots of the projection of the common center of mass (CCM) are significantly different in shape and location on the plane of support [12]. The standard protocol parameters of a statographic survey do not provide a complete picture of the human standing characteristics, but we have justified the possibility of using a primary time series for calculating the parameters of statograms, which can provide a great deal of information about the geometric parameters of the projection of the CCM onto the support plane $[1,2,7]$. Using only three statistical parameters of the series - the mathematical expectation (MO), and the minimum and maximum coordinate values - we developed an algorithm for analyzing a statogram that contains calculations of its spatial (geometric) parameters.

\section{Aim of the study}

To investigate the possibility of using spatial parameters of statograms in the assessment of pathology of the locomotor system in the case of diseases of the lumbar spine.

\section{Experimental}

Two groups of patients were examined: with osteochondrosis $(\mathrm{OCH})$ of the lumbar spine - 15 persons, with bilateral coxarthrosis (CA) III-IV stage - 15 persons, and a control group (CG) of 15 volunteers. All of the participants were from 40 to 50 years old, of normal constitution, and without concomitant neurological pathology. The studies were performed on a Statographer-01. The obtained numerical indicators were 
processed statistically; for the comparison of the groups, the analysis of variance was used [8]. Parameters have been proposed and developed that describe the planes of a statogram and their relation, the geometry of the scatter, and the angular parameters and their asymmetry. The parameters were determined for each of the three spots of a statogram, indicated by additional labels: 1 for two-legged standing, 2 for overwhelming support on the right, and 3 for the left limb.

Determined parameters of the CCM spot area (Fig. 1a): dispersion of coordinates on the $X$ and $Y$ axes $-\Delta X$ and $\Delta Y$, respectively - determining the size of the spot in the frontal and sagittal planes, the area of the spot $S=\Delta X \times \Delta Y$, respectively for two-legged and one-legged standing $-S 1, S 2, S 3$. a)

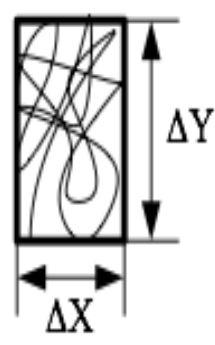

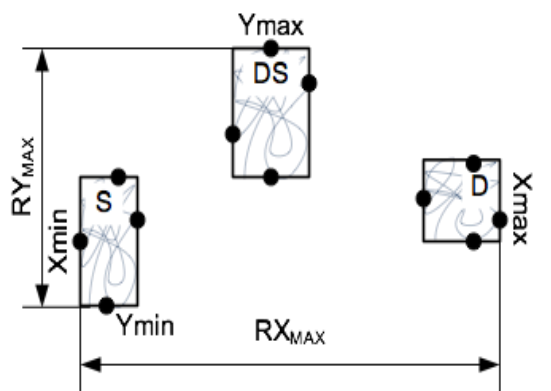

b)

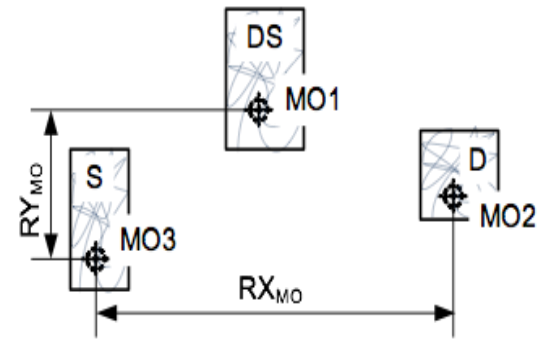

c)

Fig. 1. Statogram options for the determination of: a) CCM spot area for double and single stand $(S 1, S 2, S 3) ; b)$ total area of the statogram $\left.\left(S_{\Sigma}\right) ; c\right)$ area by value $M O$ $\left(S_{M O}\right)$

Next, we calculated the ratio of the planes of the spots of the CCM of the right limb to the area of the CCM of the left limb (1),

$$
K S_{23}=\frac{S 2}{S 1}
$$

as well as the ratio of the area of the spots of single support standing to the area of double support $(2,3)$ :

$$
\begin{aligned}
& K S_{21}=\frac{S 2}{S 1} \\
& K S_{31}=\frac{S 3}{S 1}
\end{aligned}
$$

The total surface area of the statogram $S_{\Sigma}$, calculated as the multiplication of the spread of the statogram on the $X$ axis $\left(\mathrm{RX}_{\max }\right)$ to scatter statograms along the $\mathrm{Y}$ axis $\left(R Y_{\max }\right)$. Next, we calculated the ratio of the area of the stratum to the total area of the statogram- $K_{\Sigma S 1,} K_{\Sigma S 2,} K_{\Sigma S 3}$.

We defined the area of the statogram bounded by values (MO) of the CCM full study (Fig. 1c) ( $\left.S_{M O}\right)$. To calculate this, we used the value of the spread between $\mathrm{MO}$ on the $\mathrm{X}$ axis $\left(\mathrm{RX}_{\mathrm{MO}}\right)$ and the scatter value on the $\mathrm{Y}$ axis $\left(\mathrm{RY}_{\mathrm{MO}}\right)$.

We calculated the ratio of the planes (KSS) $S_{M O}$ to $S_{\Sigma}$. The closer the ratio $K S S$ is to 1 , the smaller the scatter of the statograph from the coordinates of the placement center of the CCM. It may be an integral indicator of stability in maintaining equilibrium. The coefficient $K S S$ does not reach 1, because there is always some variation in the spot projections of CCM statograms.
Geometric analysis includes calculation of the ratio of the spot size statogram (4):

$$
K_{X Y}=\frac{\Delta X}{\Delta Y}
$$

This indicator may indicate the shape of the CCM spot. The closer the value $K_{X Y}$ is to 1 , the more the spot shape of the CCM projection approaches the square (circle). A coefficient value of 0.5 or less may indicate the elongated shape of the spot in the sagittal projection, and a value of the coefficient greater than 1 indicates the elongated shape of the spot in the frontal direction.

An ideal statogram is when a person has symmetrically located spots of the CCM of a single support, but in most cases, even in healthy people, the geometry of the spots and their location on the plane of the support have significant asymmetries. In order to identify the limits of pathological asymmetry, we have introduced a number of parameters for this analysis.

In order to analyze the scattering parameters and the asymmetry of the parameters of the statograms, in addition to the minimum and maximum coordinates, we entered the values of the MO of the coordinate being analyzed.

Using the above data, you can calculate the asymmetry parameters of the statograms in the front (on the $X$ axis) and sagittal (on the $Y$ axis) planes.

The displacement of the $\mathrm{MO}$ of the projection of the $\mathrm{CCM}$ in a single-support position relative to the $\mathrm{MO}$ of the two-support stand is calculated as the distance between the MO of the twolegged stand and the single-stand ( $\left.R X_{12,} R X_{13,} R Y_{12,} R Y_{13}\right)$ on the $X$ and $Y$ axes (Fig. 2), respectively.
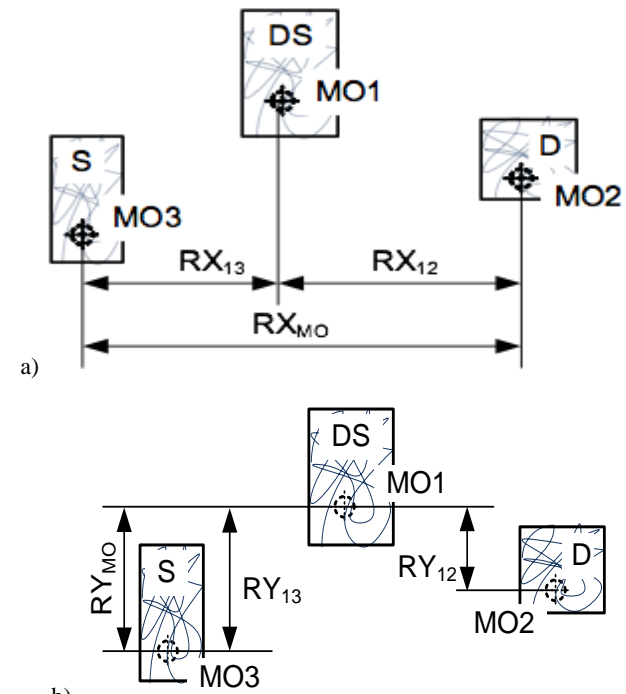

Fig. 2. Parameters of the statogram to determine: a) the scattering of the $M O$ coordinates of the single-stand CCM and the asymmetry coefficient in the front plane $(X$ axis); b) scattering $M O$ of the single-stand CCM coordinates and asymmetry coefficient in the sagittal plane ( $Y$ axis)

The asymmetry of the projection of the CCM at single support is defined as the ratio of the displacement of the CCM of the right limb to the CCM of the left limb $\left(K_{G} X, K_{G} Y\right)$. The ratio coefficient of the scatter of the statogram on the $X$ axis to the scatter on the $Y$ axis $\left(K_{G}\right)$ is defined as the ratio of the spread over the $X$ axis $\left(R X_{M O}\right)$ to the spread on the $Y$ axis $\left(R Y_{M O}\right)$ by the values of the mathematical expectation of the $X$ and $Y$ coordinates, respectively.

The physical meaning of angular asymmetry $\left(K_{\alpha}\right)$ [3] consists of the magnitude of the angles formed by the axial line along the MO $Y$ axis of the two-stand stand, the MO coordinates $(X, Y)$ of the two-stand stand, and the MO $(X, Y)$ coordinates of the projection of the single-stand CCM (Fig. 3). 

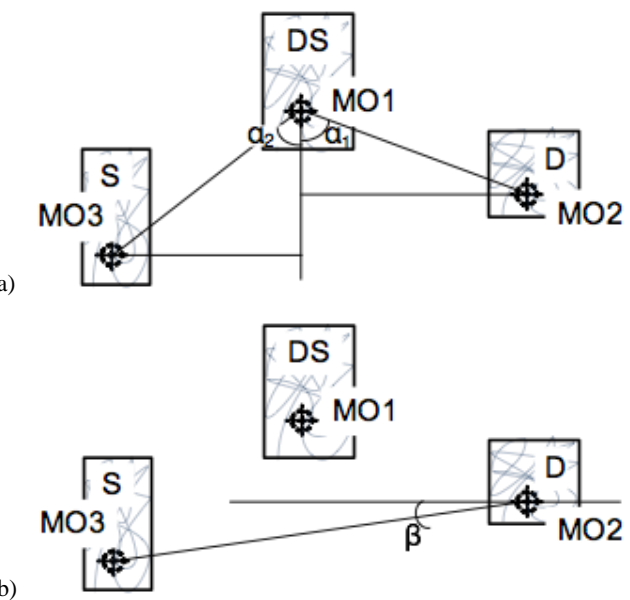

Fig. 3. Statogram parameters to determine: a) angular asymmetry coefficient; b) body turn angle

The angle of rotation of the body is determined by the triangle formed by the segment between the single-stand $\mathrm{MO}(X, Y)$ and the horizontal line constructed along the $X$ axis from the point of maximum MO of the single-stand $\mathrm{Y}$ coordinate (Fig. 3b).

\section{Results and discussion}

An analysis of the projection area of the CCM projection for each type of standing was performed (S1, S2, S3), along with the magnitude of the total maximum area of the statogram $\left(S_{\Sigma}\right)$ and its relation to the area of the projection spot with each view ( $K_{\Sigma S 1}, K_{\Sigma S 2}, K_{\Sigma S 3}$ ), the area of the statogram according to the mathematical expectation ( $S_{M O}$ ), and the relation of these planes $(K S S)$, and also the ratio of the scatter of the spots of the projection CCM on the $Y$ axis to the scatter on the $X$ axis $(K R l$, KR2, KR3) (Table 1).

The analysis showed that for all types of standing volunteers of the control group, the area of the projection spot CCM was the smallest $(231.29 \pm 118.40) \mathrm{mm}^{2}$ - during two-legged standing, and $(378.86 \pm 250.67) \mathrm{mm}^{2}$ and $(359.00 \pm 213.71) \mathrm{mm}^{2}-$ with single support predominantly to the right and left extremities, respectively. In patients with $\mathrm{OCH}$ of the lumbar spine and in patients with spacecraft, the area of the spots is much larger, with the difference being statistically significant for single support $(\mathrm{p}<0.05)$. The results of the analysis of the total area of the statogram $\left(S_{\Sigma}\right)$ by maximum values of the projection coordinates of the CCM, and the projection area of the CCM according to the coordinates of the MO $\left(S_{M O}\right)$, and coefficient analysis of area ratio (KSS) are presented in Table 2.

Therefore, the total area of the statogram, calculated by the maximum coordinate values, was not statistically significantly different $(p=0.969)$ in the groups. Also, there were no statistically different groups and values of the area of the statogram calculated by the coordinates of the mathematical expectation $(\mathrm{p}=0.524)$.

This can be explained by the fact that the area of the statogram determines the area of support within which the body of the person is in equilibrium, and going beyond these limits can lead to a fall, or to the inclusion of mechanisms of active support of equilibrium (extra step, movement of feet, movements of the hands or torso, etc.).

Unlike the planes of the chart, the ratio of the planes is statistically different between groups $(p=0.043)$. In the control group, the coefficient $K S S$ is the maximum (0.38), that is, the ability to maintain equilibrium is greatest, while the minimum $(0.25)$ was in the group of patients with CA.

The results of the ratio coefficient analysis of the area of the spot CCM for each of the standing types $(S 1, S 2, S 3)$ to the total maximum area $S_{\Sigma}$ determines the proportion that belongs to the spot area of the CCM of each standing. The results of the analysis are shown in Table 3. This coefficient determines the proportion of the spot area of the CCM for each standing.

It was found that the parameter $K_{\Sigma S}$ groups are statistically significantly different in both two-stand and single-stand. Analysis of the asymmetry of the location of the spots of the projection $\mathrm{CCM}$ in the course of a statographic study can provide a lot of information about pathological processes in the human body. Asymmetries may or may not carry pathology information, since there is no perfect symmetry in human standing.

Table 1. Analysis of spot plan $\left(R X_{M O}\right)\left(S 1, S 2, S 3\left(m^{2}\right)\right) C C M$ statograms for different types of standing in the study groups

\begin{tabular}{|c|c|c|c|c|c|c|c|c|c|c|}
\hline \multirow{2}{*}{$\begin{array}{l}\text { Kind of } \\
\text { standing }\end{array}$} & \multirow{2}{*}{ Groups } & \multirow{2}{*}{ M } & \multirow{2}{*}{ SD } & \multirow{2}{*}{ SE } & \multicolumn{2}{|c|}{$\begin{array}{l}95 \% \text { confidence interval } \\
\text { on average }\end{array}$} & \multirow{2}{*}{ MIN } & \multirow{2}{*}{ MAX } & \multicolumn{2}{|c|}{ ANOVA } \\
\hline & & & & & $\begin{array}{c}\text { Lower } \\
\text { boundary }\end{array}$ & $\begin{array}{l}\text { Upper } \\
\text { boundary }\end{array}$ & & & $\mathrm{F}$ & $\mathrm{P}$ \\
\hline \multirow{3}{*}{$\begin{array}{l}\text { Two- } \\
\text { pronged } \\
\text { standing }\end{array}$} & $\mathrm{CG}$ & 213.29 & 118.40 & 31.64 & 144.92 & 281.65 & 72.00 & 459.00 & \multirow{3}{*}{2.485} & \multirow{3}{*}{0.098} \\
\hline & $\overline{\mathrm{OCH}}$ & 495.30 & 736.28 & 232.83 & -31.40 & 1022.00 & 72.00 & 2565.00 & & \\
\hline & $\mathrm{CA}$ & 533.07 & 271.96 & 70.22 & 382.463 & 683.67 & 198.00 & 1218.00 & & \\
\hline \multirow{3}{*}{$\begin{array}{c}\text { Relying on } \\
\text { the right } \\
\text { limb }\end{array}$} & CG & 378.86 & 250.67 & 66.99 & 234.12 & 523.59 & 161.00 & 1056.00 & \multirow{3}{*}{6.846} & \multirow{3}{*}{0.003} \\
\hline & $\mathrm{OCH}$ & 401.60 & 241.72 & 76.44 & 228.68 & 574.52 & 143.00 & 1008.00 & & \\
\hline & $\mathrm{CA}$ & 807.67 & 457.73 & 118.18 & 554.19 & 1061.15 & 231.00 & 1716.00 & & \\
\hline \multirow{3}{*}{$\begin{array}{l}\text { Relying on } \\
\text { the left limb }\end{array}$} & CG & 359.00 & 213.71 & 57.12 & 235.61 & 482.39 & 108.00 & 961.00 & \multirow{3}{*}{3.874} & \multirow{3}{*}{0.030} \\
\hline & $\mathrm{OCH}$ & 537.60 & 490.70 & 155.17 & 186.58 & 888.62 & 144.00 & 1566.00 & & \\
\hline & $\mathrm{CA}$ & 756.20 & 428.71 & 110.69 & 518.79 & 993.61 & 252.00 & 1998.00 & & \\
\hline
\end{tabular}

Table 2. Plane analysis of statograms $\left(S_{\Sigma}, S_{M O}\left(\mathrm{~mm}^{2}\right)\right)$ and the ratio of the planes (KSS) in the study groups

\begin{tabular}{|c|c|c|c|c|c|c|c|c|c|c|}
\hline \multirow{2}{*}{$\begin{array}{l}\text { Kind of } \\
\text { standing }\end{array}$} & \multirow{2}{*}{ Groups } & \multirow{2}{*}{ M } & \multirow{2}{*}{ SD } & \multirow{2}{*}{ SE } & \multicolumn{2}{|c|}{$\begin{array}{l}95 \% \text { confidence interval } \\
\text { in the average }\end{array}$} & \multirow{2}{*}{ MIN } & \multirow{2}{*}{ MAX } & \multicolumn{2}{|c|}{ ANOVA } \\
\hline & & & & & $\begin{array}{c}\text { Lower } \\
\text { boundary }\end{array}$ & $\begin{array}{c}\text { Upper } \\
\text { boundary }\end{array}$ & & & $\mathrm{F}$ & $\mathrm{P}$ \\
\hline \multirow{3}{*}{$S_{\Sigma}$} & CG & 5291.50 & 1698.46 & 453.93 & 4310.84 & 6272.16 & 1824.00 & 7866.00 & \multirow{3}{*}{0.367} & \multirow{3}{*}{0.696} \\
\hline & $\mathrm{OCH}$ & 5283.30 & 1495.87 & 473.03 & 4213.22 & 6353.38 & 3275.00 & 8320.00 & & \\
\hline & $\mathrm{CA}$ & 5811.07 & 2175.71 & 561.77 & 4606.20 & 7015.93 & 2379.00 & 11060.00 & & \\
\hline \multirow{3}{*}{$S_{M O}$} & CG & 2042.10 & 949.21 & 253.69 & 1494.04 & 2590.16 & 442.61 & 3682.65 & \multirow{3}{*}{0.659} & \multirow{3}{*}{0.524} \\
\hline & $\mathrm{OCH}$ & 1679.21 & 968.65 & 306.31 & 986.28 & 2372.15 & 475.89 & 3420.38 & & \\
\hline & $\mathrm{CA}$ & 1597.89 & 1267.04 & 327.15 & 896.23 & 2299.55 & 312.78 & 5297.28 & & \\
\hline \multirow{3}{*}{$K S S$} & $\mathrm{CG}$ & 0.38 & 0.12 & 0.03 & 0.31 & 0.45 & 0.12 & 0.56 & \multirow{3}{*}{3.450} & \multirow{3}{*}{0.043} \\
\hline & $\mathrm{OCH}$ & 0.31 & 0.14 & 0.04 & 0.21 & 0.41 & 0.11 & 0.53 & & \\
\hline & $\mathrm{CA}$ & 0.25 & 0.12 & 0.03 & 0.19 & 0.32 & 0.09 & 0.48 & & \\
\hline
\end{tabular}


Table 3. Ratio coefficient analysis of $K_{S \Sigma}$ planes by groups

\begin{tabular}{|c|c|c|c|c|c|c|c|c|c|c|}
\hline \multirow{2}{*}{ Coefficients } & \multirow{2}{*}{ Groups } & \multirow{2}{*}{ M } & \multirow{2}{*}{ SD } & \multirow{2}{*}{ SE } & \multicolumn{2}{|c|}{$\begin{array}{l}95 \% \text { confidence interval } \\
\text { in the average }\end{array}$} & \multirow{2}{*}{ MIN } & \multirow{2}{*}{ MAX } & \multicolumn{2}{|c|}{ ANOVA } \\
\hline & & & & & $\begin{array}{c}\text { Lower } \\
\text { boundary }\end{array}$ & $\begin{array}{c}\text { Upper } \\
\text { boundary }\end{array}$ & & & $\mathrm{F}$ & $\mathrm{p}$ \\
\hline \multirow{3}{*}{$K_{S \Sigma 1}$} & CG & 28.54 & 10.32 & 2.76 & 22.59 & 34.50 & 16.24 & 49.02 & \multirow{3}{*}{8.395} & \multirow{3}{*}{0.001} \\
\hline & $\mathrm{OCH}$ & 20.88 & 12.08 & 3.82 & 12.24 & 29.52 & 3.24 & 45.49 & & \\
\hline & $\mathrm{CA}$ & 13.11 & 8.46 & 2.18 & 8.43 & 17.80 & 4.45 & 39.50 & & \\
\hline \multirow{3}{*}{$K_{S \Sigma 1}$} & $\mathrm{CG}$ & 16.74 & 7.09 & 1.89 & 12.65 & 20.83 & 7.24 & 27.75 & \multirow{3}{*}{1.731} & \multirow{3}{*}{0.051} \\
\hline & $\mathrm{OCH}$ & 15.94 & 8.71 & 2.75 & 9.71 & 22.17 & 8.25 & 39.44 & & \\
\hline & $\mathrm{CA}$ & 10.78 & 11.17 & 2.88 & 4.59 & 16.96 & 2.42 & 47.88 & & \\
\hline \multirow{2}{*}{$K_{S \Sigma 1}$} & $\mathrm{OCH}$ & 16.89 & 11.74 & 3.71 & 8.49 & 25.29 & 2.84 & 38.95 & \multirow[t]{2}{*}{4.585} & \multirow[t]{2}{*}{0.017} \\
\hline & $\mathrm{CA}$ & 9.22 & 4.93 & 1.27 & 6.49 & 11.95 & 2.80 & 22.99 & & \\
\hline
\end{tabular}

Table 4. Analysis of asymmetry coefficients of statogram parameters

\begin{tabular}{|c|c|c|c|c|c|c|c|c|c|c|}
\hline \multirow{2}{*}{ Coefficient } & \multirow{2}{*}{ Groups } & \multirow{2}{*}{ M } & \multirow{2}{*}{ SD } & \multirow{2}{*}{ SE } & \multicolumn{2}{|c|}{$\begin{array}{l}95 \% \text { confidence interval } \\
\text { in the average }\end{array}$} & \multirow{2}{*}{ MIN } & \multirow{2}{*}{ MAX } & \multicolumn{2}{|c|}{ ANOVA } \\
\hline & & & & & $\begin{array}{c}\text { Lower } \\
\text { boundary }\end{array}$ & $\begin{array}{c}\text { Upper } \\
\text { boundary }\end{array}$ & & & $\mathrm{F}$ & $\mathrm{P}$ \\
\hline \multirow{2}{*}{$K_{G} X$} & CG & 0.78 & 0.25 & 0.07 & 0.64 & 0.93 & 0.10 & 1.00 & \multirow{2}{*}{0.688} & \multirow{2}{*}{0.509} \\
\hline & $\mathrm{CA}$ & 0.74 & 0.25 & 0.07 & 0.60 & 0.88 & 0.17 & 0.99 & & \\
\hline \multirow{3}{*}{$K_{G} Y$} & $\mathrm{CG}$ & 0.43 & 0.24 & 0.06 & 0.29 & 0.57 & 0.01 & 0.84 & \multirow{3}{*}{0.064} & \multirow{3}{*}{0.938} \\
\hline & $\mathrm{OCH}$ & 0.45 & 0.24 & 0.08 & 0.28 & 0.62 & 0.10 & 0.84 & & \\
\hline & $\mathrm{CA}$ & 0.42 & 0.25 & 0.06 & 0.28 & 0.55 & 0.04 & 0.82 & & \\
\hline \multirow{2}{*}{$K_{G}$} & $\mathrm{OCH}$ & 0.09 & 0.05 & 0.02 & 0.05 & 0.13 & 0.02 & 0.18 & \multirow[t]{2}{*}{1.239} & \multirow{2}{*}{0.302} \\
\hline & $\mathrm{CA}$ & 0.19 & 0.24 & 0.06 & 0.06 & 0.32 & 0.04 & 0.97 & & \\
\hline
\end{tabular}

Table 5. Results of statistical analysis of coefficients $K_{\alpha}$ and $K_{\beta}$

\begin{tabular}{|c|c|c|c|c|c|c|c|c|c|c|}
\hline \multirow{2}{*}{\multicolumn{2}{|c|}{ Groups }} & \multirow{2}{*}{ M } & \multirow{2}{*}{ SD } & \multirow{2}{*}{ SE } & \multicolumn{2}{|c|}{$\begin{array}{l}95 \% \text { confidence interval } \\
\text { in the average }\end{array}$} & \multirow{2}{*}{ MIN } & \multirow{2}{*}{ MAX } & \multicolumn{2}{|c|}{ ANOVA } \\
\hline & & & & & $\begin{array}{c}\text { Lower } \\
\text { boundary }\end{array}$ & $\begin{array}{c}\text { Upper } \\
\text { boundary }\end{array}$ & & & $\mathrm{F}$ & $\mathrm{P}$ \\
\hline \multirow{2}{*}{$K_{\alpha}$} & $\mathrm{CG}$ & 0.89 & 0.08 & 0.02 & 0.84 & 0.93 & 0.78 & 0.98 & \multirow{2}{*}{4.101} & \multirow{2}{*}{0.025} \\
\hline & $\mathrm{CA}$ & 0.68 & 0.33 & 0.09 & 0.50 & 0.87 & 0.02 & 0.94 & & \\
\hline \multirow{3}{*}{$K_{\beta}$} & CG & 7.04 & 4.18 & 1.12 & 4.62 & 9.45 & 1.22 & 15.10 & \multirow{3}{*}{1.267} & \multirow{3}{*}{0.294} \\
\hline & $\mathrm{OCH}$ & 5.14 & 3.05 & 0.96 & 2.96 & 7.32 & 1.40 & 10.44 & & \\
\hline & $\mathrm{CA}$ & 9.80 & 10.84 & 2.80 & 3.80 & 15.80 & 2.03 & 43.98 & & \\
\hline
\end{tabular}

Asymmetry can indicate the nature of human standing or the presence of any asymmetries of the body without a pathological nature. Sometimes asymmetry is caused not by orthopedic, but by neurological disorders. Therefore, if asymmetry of the distribution of the parameters of the statogram occurs, then it should be paid attention to even in the presence of periodic pain syndromes, and conditions that do not yet have clinical manifestations. Such situations require further research.

The results of the analysis of the asymmetry of the scattering coordinates of the MO spots of the CCM projections at singlesupport standing in the front $\left(K_{G} X\right)$ and sagittal $\left(K_{G} Y\right)$ planes with respect to the two-support stand, as well as the coefficient of the spread between the MO $X$ and $Y$ coordinates of the full statogram are shown in Table 4 . The analysis of variance did not reveal any statistically significant difference between the groups. The $K_{G} X$ coefficient shows the asymmetry of scattering of the CCM along the $X$ axis. The analysis showed that, on average, the subjects rely equally on the right and left extremities. But if we analyze the maximum and minimum values of the $K_{G} X$ coefficient, we can see that in patients with $\mathrm{OCH}$, the minimum value of the coefficient is much greater than in the control and the group with CA. The mean value of the $K_{G} X$ coefficient is almost the same in the groups, but the median value (Table 4 ) in the CA patients is shifted toward greater asymmetry.

The coefficient of spread of $K_{G}$ was also not significantly different in the groups, but it should be noted that in patients with $\mathrm{OCH}$, the overall statogram was more stretched in the frontal plane $\left(K_{G}=0.09\right)$ than in the control $\left(K_{G}=0.12\right)$ and the group of patients with CA $\left(K_{G}=0.19\right)$. And in some patients with CA, the maximum $K_{G}$ was 0.97 , that is, the statogram was marked by a practically square boundary.
The pain syndrome on a statogram reflects the asymmetrical arrangement of the spots of the CCM under conditions of a single support with respect to the CCM of a two-support standing.

The method of determining the angular asymmetry coefficient $\left(K_{\alpha}\right)$ has already been used in laboratory studies to study the parameters of standing patients with lumbalgia and lumbosciatica. We applied this technique to analyze the statograms of all of the study groups. Pain syndrome can cause the patient to rotate the body sideways to relieve the pain while resting on one limb. This can be a conscious move or a subconscious compensatory act. Such a body rotation can be detected by analyzing the body's rotation angle $K_{\beta}$ [3]. The results of the analysis are shown in Table 5.

Analysis of variance revealed a significant difference $(\mathrm{p}=0.025)$ in asymmetry of body angle $K_{\alpha}$ between the study groups. The angle of rotation of the body in the case of single support is not statistically different in the study groups $(\mathrm{p}=0.294)$, but this indicator may reflect the pathology or pain syndrome present in $\mathrm{OCH}$ and $\mathrm{CA}$, and in a healthy person without orthopedic pathology, but with a history of injury or with congenital asymmetry within the physiological norm.

\section{Conclusions}

The spatial parameters of the statograms in the diagnosis of LS pathology are the area of projection of the CCM in one-support and two-support standing, the value of the total maximum area of the statogram and the ratio of the projection spots to each view, the area of the statogram according to the MO, and the ratio of these planes, as well as the ratio of the spots of the CCM projection on the $Y$ axis to the $X$ axis spread. The high sensitivity of the statogram parameters is indicated by the values of the CCM 
spot plane in the case of single support, the coefficients of the planes and angular asymmetry.

Based on the parameters of the statograms, it was found that for all types of standing volunteers in the control group, the area of the projection spot of the CCM was the smallest in both twostand and one-stand. In patients with $\mathrm{OCH}$ lumbar spine and from $\mathrm{CA}$ are at he stains were significantly larger, with a statistically significant difference $(\mathrm{p}<0.05)$ observed in single support. The ratio of the planes was statistically different between the groups $(\mathrm{p}=0.043)$ : in the control plane, it was the maximum $(0.38)$, which reflects the highest ability to maintain equilibrium, and the minimum (0.25) was in the group of patients with CA. Analysis of variance revealed a significant difference $(p=0.025)$ in asymmetry of body angle $K_{\alpha}$ between the study groups. The angle of rotation $K_{\beta}$ of the body in the case of single support was not statistically different in the study groups $(p=0.294)$, but this indicator can be considered as prognostic in terms of the diagnosis of LS pathology.

\section{References}

[1] Bezsmertnyi Y. O., Sergii V. P., et al: : Information model for forecasting of violation reparative osteogenesis of long bonds. Proc. SPIE 11176, 2019, $111762 \mathrm{~A}$ [http://doi.org/10.1117/12.2536250].

[2] Bezsmertnyi Y. O., Shevchuk V. I., et al.: Information model of individual rehabilitation program efficacy in disabled persons with cardiovascular diseases. Proc. SPIE 11176, 2019, 111762D [http://doi.org/10.1117/12.2536413].

[3] Bottaro A., Yasutake Y., Nomura T., Casadio M., Morasso P.: Bounded stability of the quiet standing posture: an intermittent control model. Hum Mov Sci. 27(3), 2008, 473-95 [http://doi.org/10.1016/j.humov.2007.11.005].

[4] Devetak G.F., Bohrer R.C.D., Rodacki A.L.F., Manffra E.F.: Center of mass in analysis of dynamic stability during gait following stroke: A systematic review. Gait Posture 72, 2019, 154-166 [http://doi.org/10.1016/j.gaitpost.2019.06.006].

[5] Domergue H., Rodríguez-Mañas L., Laosa Zafra O., Hood K., Gasq D. Regueme S., Sinclair A.J., Bourdel-Marchasson I.: The Use of Posturography in Investigating the Risk of Falling in Frail or Prefrail Older People with Diabetes. J Frailty Aging. 9(1), 2020, 44-50 [http://doi.org/10.14283/jfa.2019.27].

\section{Prof. Pavlov Sergii}

e-mail: psv@vntu.edu.ua

Doctor of technical sciences, professor, vice-rector for scientific work, Vinnytsia National Technical University. Research Interests: biomedical information opto-electronic and laser technologies, biomechanics, improvement of the theory of propagation of optical radiation in biological objects, creation of intelligent biomedical opto-electronic eye-processor systems for diagnostics of the basic haemodynamic parameters of the cardiovascular system.
\end{abstract}

http://orcid.org/0000-0002-0051-5560

\section{D.Sc. Bezsmertnyi Yurii}

e-mail: bezsmertnyiyurii@gmail.com

Doctor of Medical Sciences, Deputy Director for Research, Scientific Research Institute of Invalid Rehabilitation on the base of Vinnitsa Pirogov National Medical University. Research interests: diagnostics of the musculoskeletal system, biomechanics, the study of microcirculation for injuries and orthopedic diseases, computer planning of orthopedic operations, intelligent training systems in orthopedics and traumatology.

http://orcid.org/0000-0002-1388-7910

[6] Kizilova N., Karpinsky M., Griskevicius J. Daunoraviciene K.: Posturographic study of the human body vibrations for clinical diagnostics of the spine and joint pathology. Mechanika 80 (6), 2009, 37-41 [http://doi.org/10.5755/j01.mech.80.6.15500].

[7] Martinerie J., Gagey P. M.: Chaotic analysis of the stabilometric signal. M. Woollacott \& F. Horak (Eds.) Posture and gait: control mechanisms. University of Oregon Books (Portland), Tome I, 404-407.

[8] Michalak K. P., Przekoracka-Krawczyk A., Naskręcki R.: Parameters of the crossing points between center of pressure and center of mass signals are potential markers of postural control efficiency. PLoS One 14(7), 2019, e0219460 [http://doi.org/10.1371/journal.pone.0219460].

[9] Mochizuki L., Duarte M., Amadio A. C., Zatsiorsky V. M., Latash M. L. Changes in postural sway and its fractions in conditions of postural instability different postural control mechanisms. J. Appl. Biomech. 22, 2006, 51-60.

[10] Okamoto A.: Biomechanical analysis of the moment about the center of mass during the downswing phase in women's driver shot. 37th International Society of Biomechanics in Sport Conference - Proceedings Archive 37, 2019, 356-359.

[11] Rey-Martinez J., Pérez-Fernández N.: Open source posturography. Acta Otolaryngol. 136(12), 2016, 1225-1229 [http://doi.org/10.1080/00016489.2016.1204665].

[12] Ruhe A., Fejer R., Walker B.: Center of pressure excursion as a measure of balance performance in patients with non-specific low back pain compared to healthy controls: a systematic review of the literature. European Spine Journal 20(3), 2011, 358-368 [http://doi.org/10.1007/s00586-010-1543-2].

[13] Shams A., Vameghi R., Shamsipour Dehkordi P., Allafan N., Bayati M.: The development of postural control among children: Repeatability and normative data for computerized dynamic posturography system. Gait Posture 78, 2020, 40-47 [http://doi.org/10.1016/j.gaitpost.2020.03.002].

[14] Sologubov E. G., Yavorskii A. B., Kobrin V. I., Nemkova S. A., Sinel'nikova A. N.: Use of Computer Stabilography and computer-assisted biomechanical examination of gait for diagnosis of posture and movement disorders in patients with various forms of infantile cerebral paralysis. Biomed. Eng. 34(3), 2000 $138-143$.

[15] Tyazhelov O. A., Karpinsky M. Yu., Karpinska O. D., Yaremyn S. Yu.: Features of dynamic characteristics of statograms at fixation of joint of the lower extremity. Trauma 15(2), 2014, 88-93 [http://doi.org/10.22141/1608-1706.2.15.2014.81375] [in Ukrainian].

[16] Tyazhelov O.A., Fischenko V.O., Iaremin S.Yu., Karpinsky M.Yu., Karpinska O.D.: Modeling of processes of support of a vertical posture. Orthopedics, traumatology and prosthetics 598 (1), 2015, 42-49 [in Ukrainian].

[17] Yamamoto T, Smith C. E., Suzuki Y., et al.: Universal and individual characteristics of postural sway during quiet standing in healthy young adults. Physiological reports 3(3), 2015, e12329 [http://doi.org/10.14814/phy2.12329].

\begin{abstract}
Ph.D. Iaremyn Stanislav
e-mail: stanislav.iaremyn@gmail.com

Ph.D., Associate Professor of the Department of Traumatology and Orthopedics on the base of Vinnits Pirogov National Medical University. Research interests: diagnostics of the musculoskeletal system, functional chronology, biomechanics, intellectual training systems in orthopedics and traumatology.
\end{abstract}

http://orcid.org/0000-0001-9826-6859 Ph.D. Bezsmertna Halyna e-mail: bezsmertnahalyna@gmail.com

Ph.D., Candidate of Medical Sciences, Head of the Department of Rehabilitation of Persons with Disabilities, Scientific Research Institute of Invalid Rehabilitation on the base of Vinnitsa Pirogov National Medical University. Research interests: diagnostics of motor, neurological, vestibular disorders, functional chronology, biomechanics, intellectual training systems in neurology.

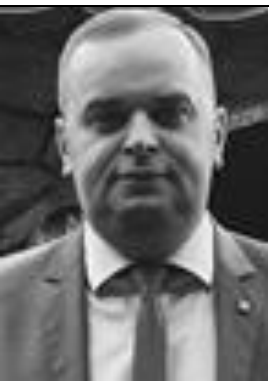

http://orcid.org/0000-0003-1505-4872 otrzymano/received: 12.07 .2020 przyjęto do druku/accepted: 15.09 .2020 